NASA/TM-2000-209891, Vol. 113

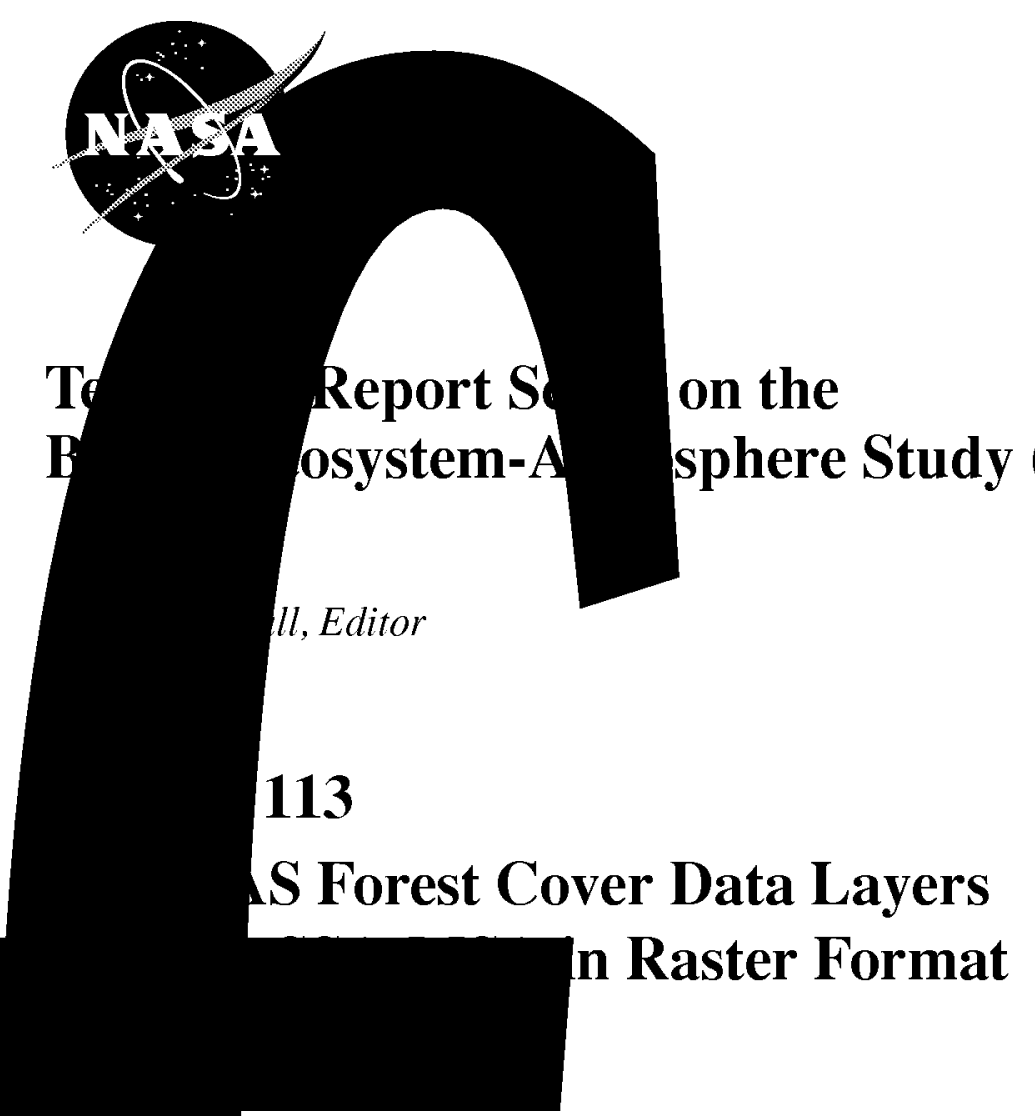

and F. Gruszka

nautics and

stration

ce Flight Center

yland 20771

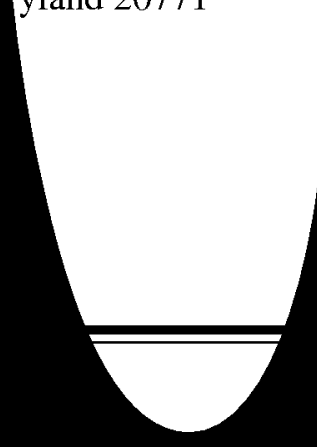


The NASA STI Program Office ... in Profile

Since its founding, NASA has been dedicated to the advancement of aeronautics and space science. The NASA Scientific and Technical Information (STI) Program Office plays a key part in helping NASA maintain this important role.

The NASA STI Program Office is operated by Langley Research Center, the lead center for NASA's scientific and technical information. The NASA STI Program Office provides access to the NASA STI Database, the largest collection of aeronautical and space science STI in the world. The Program Office is also NASA's institutional mechanism for disseminating the results of its research and development activities. These results are published by NASA in the NASA STI Report Series, which includes the following report types:

- TECHNICAL PUBLICATION. Reports of completed research or a major significant phase of research that present the results of NASA programs and include extensive data or theoretical analysis. Includes compilations of significant scientific and technical data and information deemed to be of continuing reference value. NASA's counterpart of peer-reviewed formal professional papers but has less stringent limitations on manuscript length and extent of graphic presentations.

- TECHNICAL MEMORANDUM. Scientific and technical findings that are preliminary or of specialized interest, e.g., quick release reports, working papers, and bibliographies that contain minimal annotation. Does not contain extensive analysis.

- CONTRACTOR REPORT. Scientific and technical findings by NASA-sponsored contractors and grantees.
- CONFERENCE PUBLICATION. Collected papers from scientific and technical conferences, symposia, seminars, or other meetings sponsored or cosponsored by NASA.

- SPECIAL PUBLICATION. Scientific, technical, or historical information from NASA programs, projects, and mission, often concerned with subjects having substantial public interest.

- TECHNICAL TRANSLATION. English-language translations of foreign scientific and technical material pertinent to NASA's mission.

Specialized services that complement the STI Program Office's diverse offerings include creating custom thesauri, building customized databases, organizing and publishing research results ... even providing videos.

For more information about the NASA STI Program Office, see the following:

- Access the NASA STI Program Home Page at http://www.sti.nasa.gov/STI-homepage.html

- E-mail your question via the Internet to help@sti.nasa.gov

- Fax your question to the NASA Access Help Desk at (301) 621-0134

- Telephone the NASA Access Help Desk at (301) 621-0390

- Write to:

NASA Access Help Desk

NASA Center for AeroSpace Information 7121 Standard Drive Hanover, MD 21076-1320 
NASA/TM-2000-209891, Vol. 113

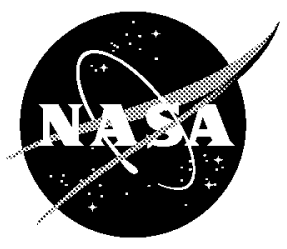

Technical Report Series on the Boreal Ecosystem-Atmosphere Study (BOREAS)

Forrest G. Hall, Editor

\section{Volume 113}

\section{BOREAS Forest Cover Data Layers over the SSA-MSA in Raster Format}

Jaime Nickeson, Raytheon ITSS, NASA Goddard Space Flight Center, Greenbelt, Maryland

Fern Gruszka, Saskatchewan Environment and Resource Management (SERM), Prince Albert, SK, Canada

National Aeronautics and Space Administration

Goddard Space Flight Center

Greenbelt, Maryland 20771 


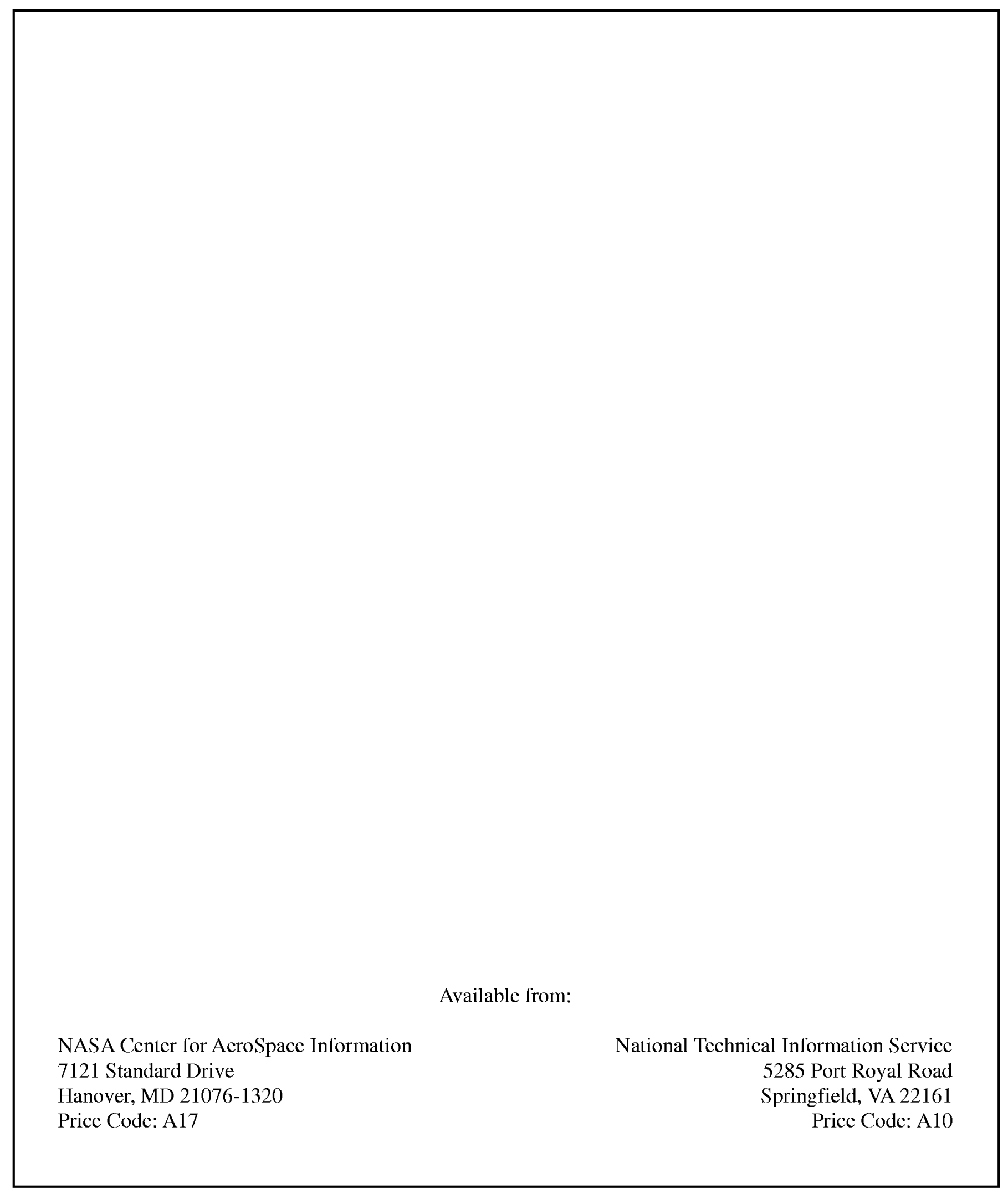




\title{
BOREAS Forest Cover Data Layers over the SSA-MSA in Raster Format
}

\author{
Jaime Nickeson, Fern Gruszka
}

\section{Summary}

This data set, originally provided as vector polygons with attributes, has been processed by BORIS staff to provide raster files that can be used for modeling or for comparison purposes. The original data were received as ARC/INFO coverages or as export files from SERM. The data include information on forest parameters for the BOREAS SSA-MSA. Most of the data used for this product were acquired by BORIS in 1993; the maps were produced from aerial photography taken as recently as 1988 . The data are stored in binary, image format files.

Note that the binary files of this data set on the BOREAS CD-ROMs have been compressed using the Gzip program. See Section 8.2 for details.

\section{Table of Contents}

1) Data Set Overview

2) Investigator(s)

3) Theory of Measurements

4) Equipment

5) Data Acquisition Methods

6) Observations

7) Data Description

8) Data Organization

9) Data Manipulations

10) Errors

11) Notes

12) Application of the Data Set

13) Future Modifications and Plans

14) Software

15) Data Access

16) Output Products and Availability

17) References

18) Glossary of Terms

19) List of Acronyms

20) Document Information

\section{Data Set Overview}

\subsection{Data Set Identification}

BOREAS Forest Cover Data Layers over the SSA-MSA in Raster Format

\subsection{Data Set Introduction}

The forest cover data layers were created in raster form from the vector polygon forest cover data provided by Saskatchewan Environment and Resource Management, Forestry Branch - Inventory Unit (SERM-FBIU). The forest cover data layers created for this product are species cover, canopy closure, height, and year. 


\subsection{Objective/Purpose}

These data are provided as part of the BOReal Ecosystem-Atmosphere Study (BOREAS) Staff Science Geographical Information system (GIS) Data Collection Program, which included the collection of pertinent map data in both hardcopy and digital form. This data set, originally provided as vector polygons with attributes, has been processed to provide raster files that can be used for modeling or for comparison purposes.

\subsection{Summary of Parameters}

The parameters that are in the raster data include species association (cover type), crown closure, height class, and decadal year of stand origin or disturbance.

\subsection{Discussion}

Based on a review of the data and discussions with SERM personnel and BOREAS scientists, BOREAS Information System (BORIS) staff processed the original vector data into raster data layers. A full description of the data layer derivations is given in Section 9.

\subsection{Related Data Sets}

BOREAS Forest Cover Data Layers of the NSA-MSA in Raster Format

SERM Forest Cover Data Layers of the SSA in Vector Format

SERM Forest Fire Chronology of Saskatchewan in Vector Format

SERM Forest Cover Data of Saskatchewan in Vector Format

Prince Albert National Park Forest Cover Data in Vector Format

\section{Investigator(s)}

\subsection{Investigator(s) Name and Title}

BOREAS Staff Science

\subsection{Title of Investigation}

BOREAS Staff Science GIS Data Collection Program

\subsection{Contact Information}

\section{Contact 1:}

Fern Gruszka

Saskatchewan Environment and Resource Management

800 Central Ave.

Prince Albert, SK

CANADA S6V 6G1

(306) 953-2360

gruszka@larix.derm.gov.sk.ca

\section{Contact 2:}

Jaime Nickeson

Raytheon ITSS

Code 923

NASA GSFC

Greenbelt, MD 20771

(301) 286-3373

(301) 286-0239 (fax)

Jaime.Nickeson@gsfc.nasa.gov 


\section{Theory of Measurements}

SERM-FBIU maintains in its inventory unit a GIS of forest inventory information for Saskatchewan. This inventory is maintained primarily for use by forest managers for silvicultural purposes, and it contains a wealth of information that can be of use in Earth resources analyses and ecosystem modeling either in its raw form or as a derived product such as this one.

\section{Equipment}

\subsection{Sensor/Instrument Description}

The original polygon data were digitized from 1:12,500-scale forest cover maps. The maps were derived from black-and-white 1:12,500-scale infrared aerial photography and field reconnaissance notes. No information is known about the original digitizing equipment or procedures and criteria used in the digitizing process.

\subsubsection{Collection Environment}

These original vector data were acquired as ARC/INFO vector coverages or in ARC/INFO export format. The data were produced by SERM-FBIU. No specific information other than the scale of the resulting photography is known about the aircraft flights or the equipment that was used to collect the aerial photography.

\subsubsection{Source/Platform} Unknown.

\subsubsection{Source/Platform Mission Objectives} Unknown.

\subsubsection{Key Variables}

The key variables of this data set are species cover, crown closure, height class, and decadal year of stand origin or disturbance.

\subsubsection{Principles of Operation} Unknown.

\subsubsection{Sensor/Instrument Measurement Geometry} Unknown.

\subsubsection{Manufacturer of Sensor/Instrument}

Unknown.

\subsection{Calibration}

Unknown.

\subsubsection{Specifications}

Unknown.

\subsubsection{Tolerance} Unknown.

\subsubsection{Frequency of Calibration Unknown.}




\subsubsection{Other Calibration Information}

None.

\section{Data Acquisition Methods}

SERM personnel created the forest cover maps by transcribing information from photo-interpreted 1:12,500-scale black-and-white infrared aerial photography and field reconnaissance notes.

\section{Observations}

\subsection{Data Notes}

None.

\subsection{Field Notes}

The field notes used in compiling the original forest cover data are available from SERM-FBIU. See Section 2.3.

\section{Data Description}

\subsection{Spatial Characteristics}

\subsubsection{Spatial Coverage}

This data set covers a portion of the BOREAS Southern Study Area (SSA) and encompasses most of the associated SSA-Modeling Sub-Area (MSA). The corners of the actual raster data files are:

\begin{tabular}{|c|c|c|c|c|}
\hline Point & $\begin{array}{l}\text { BOREAS } \\
X \quad(k m)\end{array}$ & $\begin{array}{l}\text { BOREAS } \\
Y \quad(\mathrm{~km})\end{array}$ & $\begin{array}{c}\text { West } \\
\text { Longitude }\end{array}$ & $\begin{array}{c}\text { North } \\
\text { Latitude }\end{array}$ \\
\hline Upper Right & 425.160 & 360.840 & 104.49043 & 54.06 \\
\hline Upper Left & 381.870 & 360.840 & 105.14995 & 54.098 \\
\hline Lower Left & 381.870 & 326.490 & 105.19373 & 53.791 \\
\hline Lower Right & 425.160 & 326.490 & 104.53910 & 53.757 \\
\hline
\end{tabular}

These locations represent the outside corners of the corner pixels.

\subsubsection{Spatial Coverage Map}

Not available.

\subsubsection{Spatial Resolution}

These data were gridded to a cell size of $30 \mathrm{~m}$. 


\subsubsection{Projection}

The area mapped is projected in the BOREAS grid projection, which is based on the ellipsoidal version of the Albers Equal-Area Conic (AEAC) projection. The projection has the following parameters:

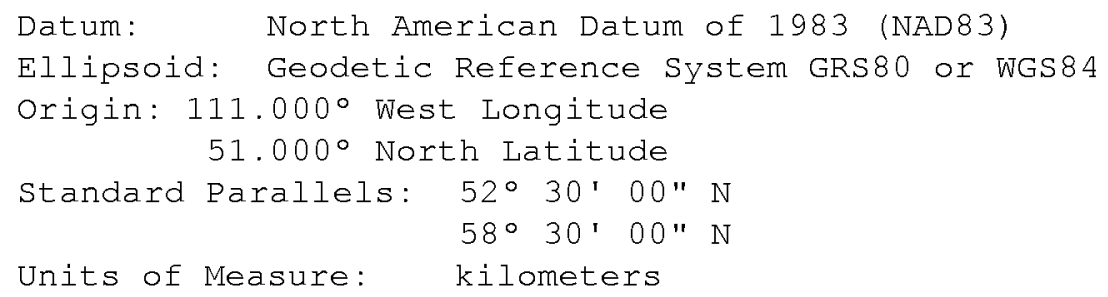

\subsubsection{Grid Description}

The data are gridded in 30-m intervals based on the ellipsoidal version of the AEAC projection with standard parallels of $52^{\circ} 30^{\prime} \mathrm{N}$ and $58^{\circ} 30^{\prime} \mathrm{N}$ and a lower left origin of $51^{\circ} \mathrm{N}$ and $111^{\circ} \mathrm{W}$.

\subsection{Temporal Characteristics}

Most of the data used for this product were acquired by BORIS in 1993. The maps from which the data are derived are completely reinventoried on a 10- to 20-year cycle by SERM, except for disturbed areas, which are updated annually. BORIS acquired the data in 1993; the forest cover layers have not yet had any inventory updates.

\subsubsection{Temporal Coverage}

These maps were produced from aerial photography taken as recently as 1988 . The data base maintained by SERM is updated as needed based on fires, cutting, or other disturbances.

\subsubsection{Temporal Coverage Map}

Not available.

\subsubsection{Temporal Resolution}

As noted, the original maps are completely reinventoried by SERM personnel on a 10- to 20-year cycle, except for disturbed areas, which are updated annually. The photographs and other information used to create the original vector data set most likely covered the 10 - to 20 -year period prior to 1988 and any updates made from then to 1993, when the data were acquired.

\subsection{Data Characteristics}

\subsubsection{Parameter/Variable}

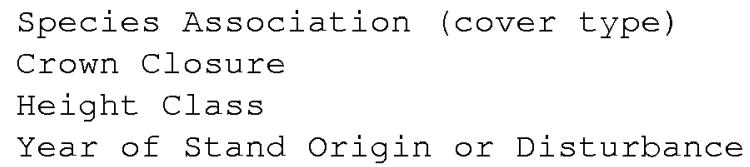

\subsubsection{Variable Description/Definition}

- Species Association - The vegetative species association covering the given area as derived by BORIS personnel. See Section 9 for derivation details.

- Crown Closure: The crown closure category specified in the original data set. See Section 9 for derivation details.

- Height Class: The height class of the vegetation covering the area. See Section 9 for class details.

- Year of Stand Origin or Disturbance: The decade in which the vegetation in the area originated or the year it was last disturbed. See Section 9 for coding details. 


\subsubsection{Unit of Measurement}

The values in each of the data layers are described as follows:

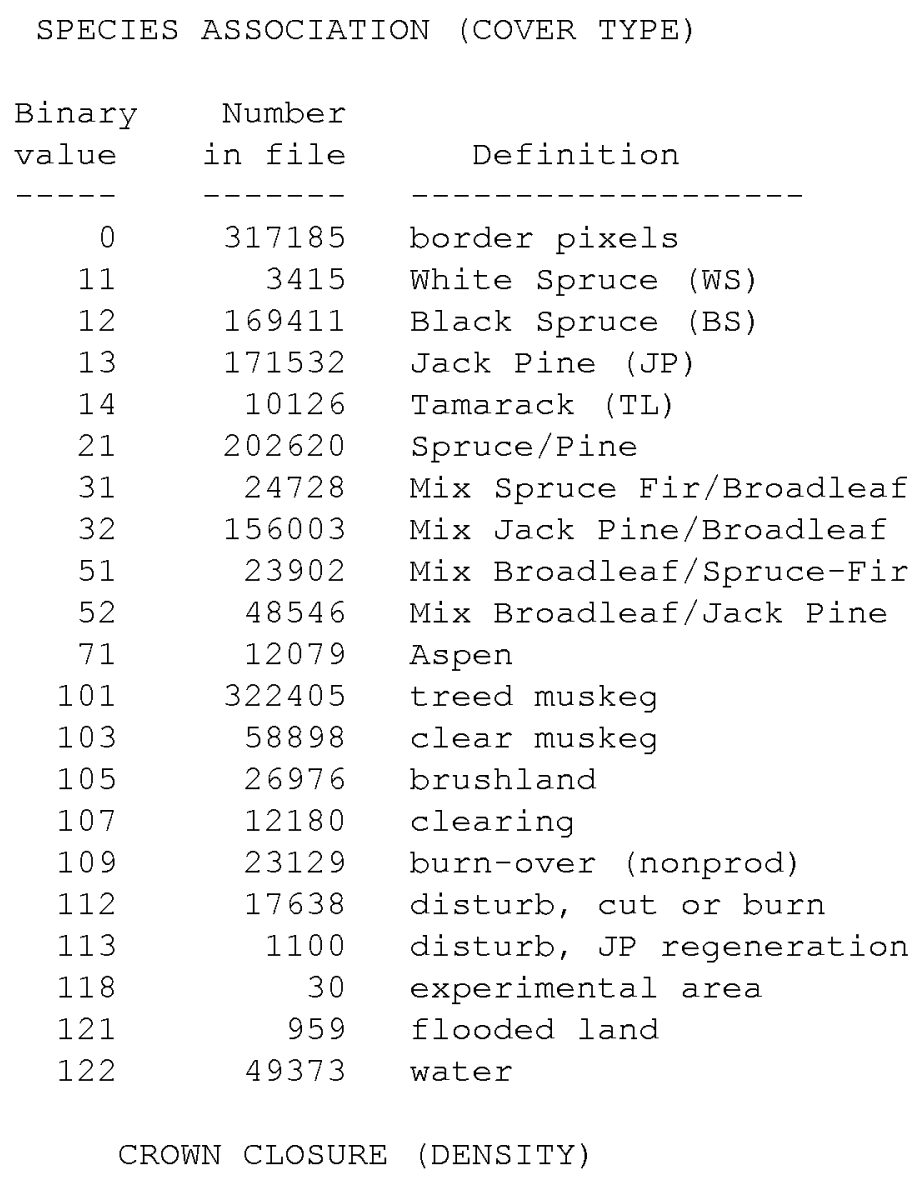

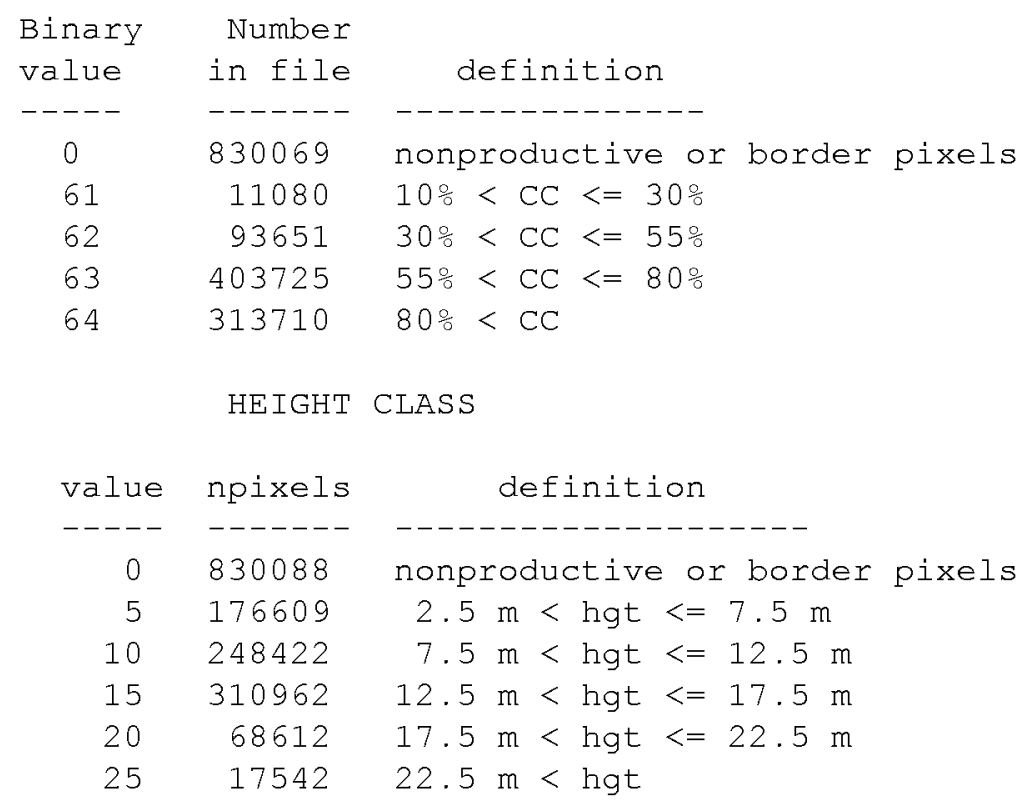




\begin{tabular}{|c|c|c|}
\hline value & npixels & definition \\
\hline----- & ------- & ----------------- \\
\hline 0 & 811127 & nonproductive or border pixels \\
\hline 82 & 33 & 1815-1825 Year of stand origin \\
\hline 83 & 1378 & $1825-1835$ \\
\hline 84 & 2496 & $1835-1845$ \\
\hline 85 & 18158 & $1845-1855$ \\
\hline 86 & 30086 & $1855-1865$ \\
\hline 87 & 12824 & $1865-1875$ \\
\hline 88 & 62706 & $1875-1885$ \\
\hline 89 & 90075 & $1885-1895$ \\
\hline 90 & 104530 & $1895-1905$ \\
\hline 91 & 75163 & $1905-1915$ \\
\hline 92 & 116326 & $1915-1925$ \\
\hline 93 & 30494 & $1925-1935$ \\
\hline 94 & 112734 & $1935-1945$ \\
\hline 95 & 10165 & $1945-1955$ \\
\hline 96 & 2283 & $1955-1965$ \\
\hline 97 & 39688 & $1965-1975$ \\
\hline 98 & 113392 & $1975-1985$ \\
\hline 176 & 103 & 1976 Year of disturbance \\
\hline 177 & 51 & 1977 \\
\hline 180 & 51 & 1980 \\
\hline 183 & 8 & 1983 \\
\hline 184 & 7232 & 1984 \\
\hline 185 & 4951 & 1985 \\
\hline 186 & 6181 & 1986 \\
\hline
\end{tabular}

\subsubsection{Data Source}

The original data were acquired in ARC/INFO format from:

Saskatchewan Environment and Resource Management

Forestry Branch - Inventory Unit

800 Central Ave.

Prince Albert, Saskatchewan

Canada S6V 6G1

The original data were gridded into a binary image format for the SSA-MSA by BORIS personnel.

\subsubsection{Data Range}

$\begin{array}{llr}\text { Species Association } & 0 & -122 \\ \text { Crown Closure } & 0 & -64 \\ \text { Height Class } & 0 & -25 \\ \text { Year of Stand Origin or Disturbance } & 0 & -186\end{array}$

\subsection{Sample Data Record}

Not applicable. 


\section{Data Organization}

\subsection{Data Granularity}

The smallest amount of obtainable data is the entire data set containing the four raster layers and other supporting files.

\subsection{Data Format(s)}

The raster data are stored on tape as single-byte band-sequential binary files.

\subsubsection{Uncompressed Data Files}

The data files include:

\begin{tabular}{|c|c|c|c|c|}
\hline File & Descrintion & Record & Number of & Bytes/Pixel \\
\hline & & & & \\
\hline 1 & Header File & 80 & 19 & $\mathrm{~N} / \mathrm{A}$ \\
\hline 2 & SPECIES COVER & 1443 & 1145 & 1 \\
\hline 3 & CROWN CLOSURE & 1443 & 1145 & 1 \\
\hline 4 & HEIGHT & 1443 & 1145 & 1 \\
\hline 5 & YEAR & 1443 & 1145 & 1 \\
\hline 6 & AML 1 (calc cover, year) & 80 & 79 & $\mathrm{~N} / \mathrm{A}$ \\
\hline 7 & AML 2 (create grid, combine) & 80 & 129 & $N / A$ \\
\hline 8 & AML 3 (reprojection info) & 80 & 10 & $\mathrm{~N} / \mathrm{A}$ \\
\hline
\end{tabular}

The data set consists of eight files. The first file is the header file, which contains 80-byte records of American Standard Code for Information Interchange (ASCII) characters that describe the general content of the data set.

Files 2 through 5 contain the binary raster data layers. Each raster layer contains 1,443 8-bit (1-byte) values in each of 1,145 lines.

Files 6 through 8 contain ASCII files that provide examples of the type of ARC Macro Language (AML) files used to create this data set from the original vector data. These files were not intended to be used directly; they are merely examples of the process undertaken to produce the provided data set.

\subsubsection{Compressed CD-ROM Files}

On the BOREAS CD-ROMs, files 1, 6, 7, and 8 listed above are stored as ASCII text files; however, files 2 - 4 have been compressed with the Gzip compression program (file name *.gz). These data have been compressed using gzip version 1.2.4 and the high compression (-9) option (Copyright (C) 1992-1993 Jean-loup Gailly). Gzip (GNU zip) uses the Lempel-Ziv algorithm (Welch, 1994) used in the zip and PKZIP programs. The compressed files may be uncompressed using gzip (-d option) or gunzip. Gzip is available from many Web sites (for example, ftp site prep.ai.mit.edu/pub/gnu/gzip-**) for a variety of operating systems in both executable and source code form. Versions of the decompression software for various systems are included on the CD-ROMs.

\section{Data Manipulations}

\subsection{Formulae}

The original data were acquired as ARC/INFO export files, one file per $10-\mathrm{km} \times 10-\mathrm{km}$ area. The data were imported into ARC, and attributes of the coverage polygons were manipulated within AML scripts to produce new attributes. The new attributes were used as lookup tables for gridding the data, and the separate maps were then mosaicked together into one map for each layer/attribute. The relevant attributes (items) associated with each polygon in the vector data are as follows: 


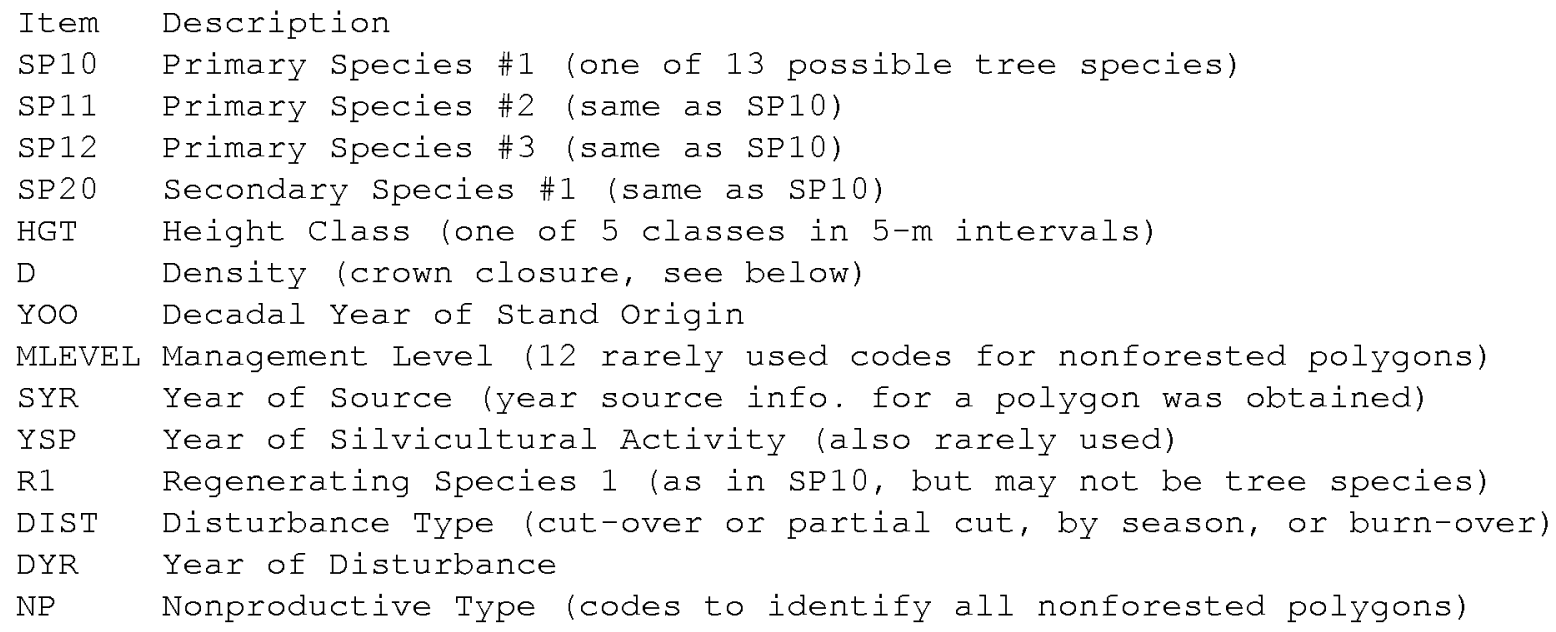

The data layers created for this product were derived from the above attributes as follows:

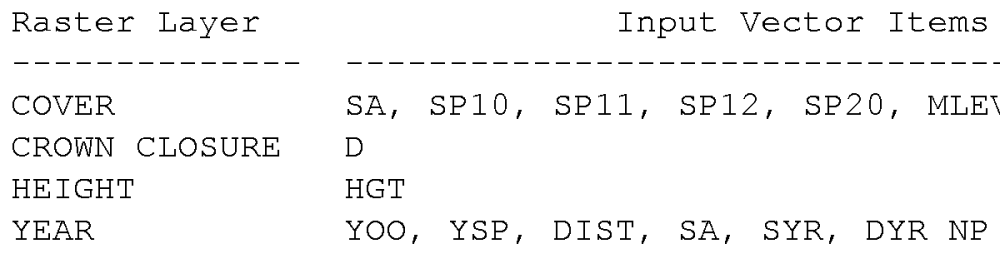

\subsubsection{Derivation Techniques and Algorithms}

The species association data use the items listed above to select one of the 18 species associations as defined by SERM, who provided the data. The minimum size for homogeneous forest stands varies from 1-4 hectares depending upon the size (HGT) and economic value of the species.

The crown closure data were created using the D item within the coverages. This item is the average percent crown closure of the forest stand and is assigned to one of four classes. The boundaries of these classes are given in the table in Section 8.2. Values for item D exist only for forested polygons.

The height class data were created from the HGT item within the coverages. The average height of all living trees in the main canopy of the stand is assigned to one of five height classes. The limits of the height classes are given in Section 8.2. Values for item HGT exist only for forested polygons.

The decadal year of origin or disturbance data were derived from a combination of the items listed above. In the table in Section 8.2, year of silvicultural treatment and year of disturbance are coded similarly. The ages of productive polygons were assigned to decadal classes. When ages overlap two or more classes, the older class is usually chosen. Values for the year-associated items exist only for forested or disturbed polygons.

\subsection{Data Processing Sequence}

\subsubsection{Processing Steps}

Most of the following processing steps were performed in ARC/INFO.

- New attribute items were added to the attribute files of each coverage to store the value that would represent cover, crown closure, and year of stand origin

- HGT was already a numeric item and could be used directly as a lookup table for gridding the height layer.

- Crown closure was not numeric, but levels were easily converted to a numeric item that was used to grid the height layer.

- New values were assigned to the new cover item using the SERM definition of species association, which assigns one of 18 common boreal associations from the many possible 
combinations of the SP10, SP11, and SP12 (only 10 different species associations show up in this data set).

- Management level, regenerating species, disturbance type, and nonproductive code were used to assign cover values for nonforested polygons.

- To calculate the year item, the year of stand origin item was used for forested polygons, and year of disturbance or source year was used for nonforested polygons.

- The numeric items created for cover and year were then used to grid the polygons for those layers.

- The individual maps that had been gridded were mosaicked using the ARC function GRIDINSERT.

- The resulting Universal Transverse Mercator (UTM) layer maps were reprojected in ARC to create the raster images in the BOREAS grid projection.

- The gridded layers and other information files were written to tape for distribution.

- $\quad$ BORIS staff copied the ASCII and compressed the binary files for release on CD-ROM.

\subsubsection{Processing Changes}

None.

\subsection{Calculations}

\subsubsection{Special Corrections/Adjustments}

None.

\subsubsection{Calculated Variables}

None.

\subsection{Graphs and Plots}

None.

\section{Errors}

\subsection{Sources of Error}

There is the possibility of coding errors in the attributes, transcription errors from original sample data, and photo-interpretation errors.

\subsection{Quality Assessment}

\subsubsection{Data Validation by Source}

Unknown.

\subsubsection{Confidence Level/Accuracy Judgment}

The accuracy of the gridding procedure is high. Some consideration should be given to the scale of the data and what will be inferred from it.

\subsubsection{Measurement Error for Parameters Unknown.}

\subsubsection{Additional Quality Assessments}

None. 


\subsubsection{Data Verification by Data Center}

Each gridded image was checked visually to make sure that the gridding procedure assigned a digital number (DN) to each attribute value. The data were also checked for gaps of "no data" along the seams of the $10-\mathrm{km} \times 10-\mathrm{km}$ coverages used to compile this product.

\section{Notes}

\subsection{Limitations of the Data}

BORIS acquired these data in 1993; therefore, areas subjected to logging activity or other disturbance, such as fire, will appear much different today as compared to the forest cover data.

\subsection{Known Problems with the Data}

None.

\subsection{Usage Guidance}

Saskatchewan Parks and Renewable Resources does not accept any liability for decisions or action taken on the basis of these data.

Before uncompressing the Gzip files on CD-ROM, be sure that you have enough disk space to hold the uncompressed data files. Then use the appropriate decompression program provided on the CD-ROM for your specific system.

\subsection{Other Relevant Information}

Saskatchewan Parks and Renewable Resources also maintains stand and stock tables, 3P plots, and possibly some permanent sample plots in this area. Aerial photographic prints and negatives are also available. Contact the agency directly if you are interested in such information or if you wish to acquire those data.

\section{Application of the Data Set}

This data set would provide good reference information for assessing spectral image data classification techniques over the area and serve as an initial baseline data set for analyzing land cover and vegetation change.

\section{Future Modifications and Plans}

None.

\section{Software}

\subsection{Software Description}

The Environmental Systems Research Institute (ESRI) ARC/INFO (Version 7.0) package was used to perform the data manipulation and processing. Questions about the software should be directed to ESRI. Gzip (GNU zip) uses the Lempel-Ziv algorithm (Welch, 1994) used in the zip and PKZIP commands.

\subsection{Software Access}

ARC/INFO is proprietary software with copyright protection. Contact ESRI for details: 
Environmental Systems Research Institute, Inc. (ESRI)

380 New York St.

Redlands, CA 92373-8100

Gzip is available from many Web sites across the Internet (for example, ftp site

prep.ai.mit.edu/pub/gnu/gzip-*.*) for a variety of operating systems in both executable and source code form. Versions of the decompression software for various systems are included on the CD-ROMs.

\section{Data Access}

The BOREAS forest cover data layers over the SSA-MSA in raster format are available from the Earth Observing System Data and Information System (EOSDIS) Oak Ridge National Laboratory (ORNL) Distributed Active Archive Center (DAAC).

\subsection{Contact Information}

For BOREAS data and documentation please contact:

ORNL DAAC User Services

Oak Ridge National Laboratory

P.O. Box 2008 MS-6407

Oak Ridge, TN 37831-6407

Phone: (423) 241-3952

Fax: (423) 574-4665

E-mail: ornldaac@ornl.gov or orn1@eos.nasa.gov

\subsection{Data Center Identification}

Earth Observing System Data and Information System (EOSDIS) Oak Ridge National Laboratory (ORNL) Distributed Active Archive Center (DAAC) for Biogeochemical Dynamics http://www-eosdis.ornl.gov/.

\subsection{Procedures for Obtaining Data}

Users may obtain data directly through the ORNL DAAC online search and order system [http://www-eosdis.ornl.gov/] and the anonymous FTP site [ftp://www-eosdis.ornl.gov/data/] or by contacting User Services by electronic mail, telephone, fax, letter, or personal visit using the contact information in Section 15.1.

\subsection{Data Center Status/Plans}

The ORNL DAAC is the primary source for BOREAS field measurement, image, GIS, and hardcopy data products. The BOREAS CD-ROM and data referenced or listed in inventories on the CD-ROM are available from the ORNL DAAC.

\section{Output Products and Availability}

\subsection{Tape Products}

None.

\subsection{Film Products}

None. 


\subsection{Other Products}

These data are available on the BOREAS CD-ROM series.

\section{References}

\subsection{Platform/Sensor/Instrument/Data Processing Documentation} ARC/INFO User's Guide (Version 7). 1994. Redlands, CA.

Welch, T.A. 1984. A Technique for High Performance Data Compression. IEEE Computer, Vol. 17, No. 6, pp. 8-19.

\subsection{Journal Articles and Study Reports}

Lindenas, D.G. June 1985. Forest Inventory Interpretation and Mapping Manual - Specifications for the Interpretation and Mapping of Aerial Photographs in the Forest Inventory Section. Saskatchewan Parks and Renewable Resources

Newcomer, J., D. Landis, S. Conrad, S. Curd, K. Huemmrich, D. Knapp, A. Morrell, J. Nickeson, A. Papagno, D. Rinker, R. Strub, T. Twine, F. Hall, and P. Sellers, eds. 2000. Collected Data of The Boreal Ecosystem-Atmosphere Study. NASA. CD-ROM.

Sellers, P. and F. Hall. 1994. Boreal Ecosystem-Atmosphere Study: Experiment Plan. Version 1994-3.0, NASA BOREAS Report (EXPLAN 94).

Sellers, P. and F. Hall. 1996. Boreal Ecosystem-Atmosphere Study: Experiment Plan. Version 1996-2.0, NASA BOREAS Report (EXPLAN 96).

Sellers, P., F. Hall, and K.F. Huemmrich. 1996. Boreal Ecosystem-Atmosphere Study: 1994 Operations. NASA BOREAS Report (OPS DOC 94).

Sellers, P., F. Hall, and K.F. Huemmrich. 1997. Boreal Ecosystem-Atmosphere Study: 1996 Operations. NASA BOREAS Report (OPS DOC 96).

Sellers, P., F. Hall, H. Margolis, B. Kelly, D. Baldocchi, G. den Hartog, J. Cihlar, M.G. Ryan, B. Goodison, P. Crill, K.J. Ranson, D. Lettenmaier, and D.E. Wickland. 1995. The boreal ecosystem-atmosphere study (BOREAS): an overview and early results from the 1994 field year. Bulletin of the American Meteorological Society. 76(9):1549-1577.

Sellers, P.J., F.G. Hall, R.D. Kelly, A. Black, D. Baldocchi, J. Berry, M. Ryan, K.J. Ranson, P.M. Crill, D.P. Lettenmaier, H. Margolis, J. Cihlar, J. Newcomer, D. Fitzjarrald, P.G. Jarvis, S.T. Gower, D. Halliwell, D. Williams, B. Goodison, D.E. Wickland, and F.E. Guertin. 1997. BOREAS in 1997: Experiment Overview, Scientific Results and Future Directions. Journal of Geophysical Research 102 (D24): 28,731-28,770.

\subsection{Archive/DBMS Usage Documentation None.}

\section{Glossary of Terms}

None. 


\section{List of Acronyms}

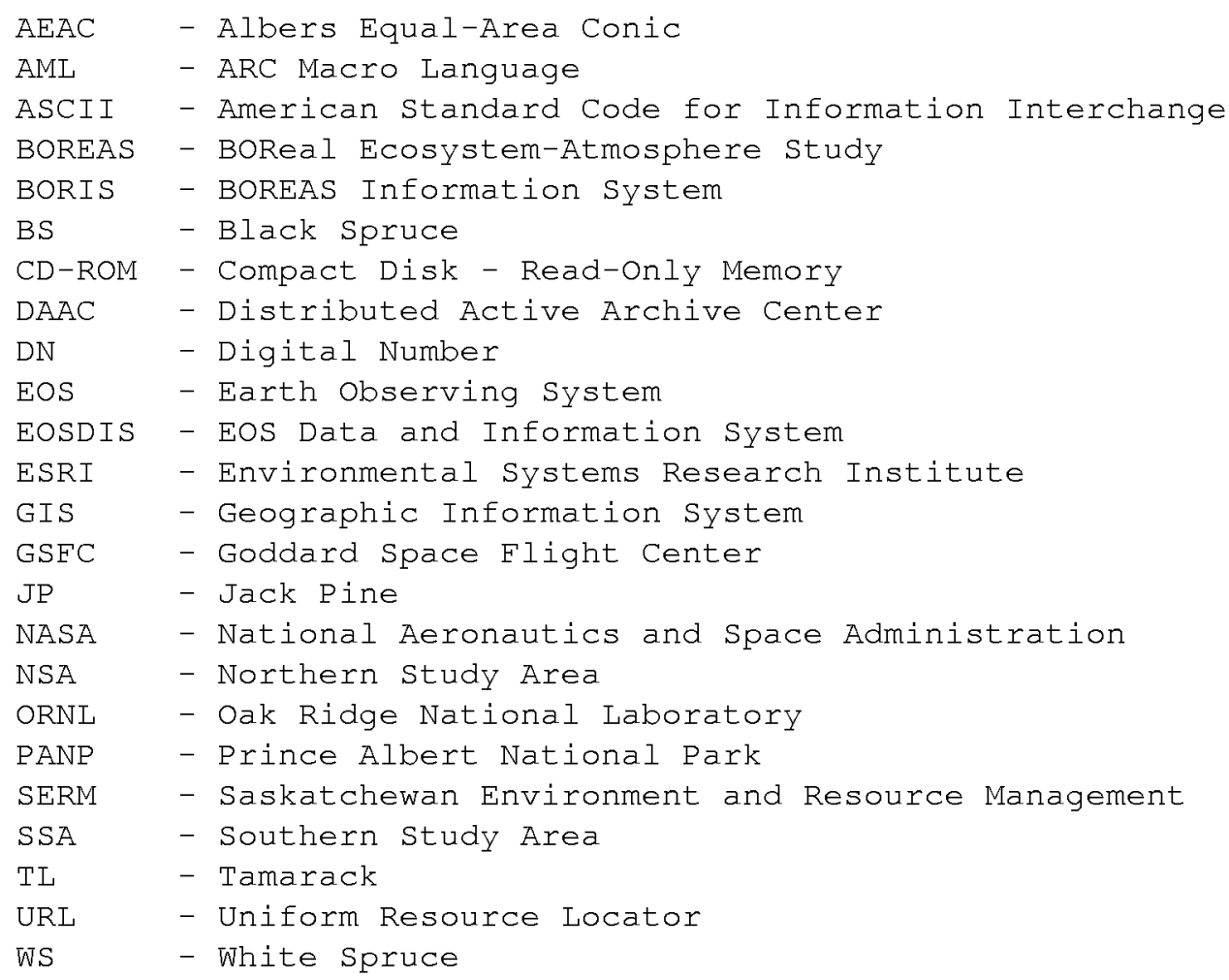

\section{Document Information}

\subsection{Document Revision Dates}

Written: 01-Aug-1994

Last Updated: 03-Feb-1999

\subsection{Document Review Dates}

BORIS Review: 15-May-1997

Science Review:

\subsection{Document ID}

\subsection{Citation}

When using these data, please include the following acknowledgment as well as citations of relevant papers in Section 17.2:

The original data were provided by SERM-FBIU. The vector data were processed and gridded by BORIS staff. The contribution of the vector data by SERM and the processing of the data by BORIS staff are greatly appreciated.

If using data from the BOREAS CD-ROM series, also reference the data as:

BOREAS Staff Science, "BOREAS Staff Science GIS Data Collection Program." In Collected Data of The Boreal Ecosystem-Atmosphere Study. Eds. J. Newcomer, D. Landis, S. Conrad, S. Curd, K. Huemmrich, D. Knapp, A. Morrell, J. Nickeson, A. Papagno, D. Rinker, R. Strub, T. Twine, F. Hall, and P. Sellers. CD-ROM. NASA, 2000. 
Also, cite the BOREAS CD-ROM set as:

Newcomer, J., D. Landis, S. Conrad, S. Curd, K. Huemmrich, D. Knapp, A. Morrell, J.

Nickeson, A. Papagno, D. Rinker, R. Strub, T. Twine, F. Hall, and P. Sellers, eds. Collected Data of The Boreal Ecosystem-Atmosphere Study. NASA. CD-ROM. NASA, 2000.

\subsection{Document Curator}

\subsection{Document URL}


Public reporting burden for this collection of information is estimated to average 1 hour per response, including the time for reviewing instructions, searching existing data sources, gathering and maintaining the data needed and completing and reviewing the collection of information. Send comments regarding this burden estimate or any other aspect of this collection of information including suggestions for reducing this burden, to Washington Headquaters Services, Directorate for Information Operations and Reports, 1215 Jefferson Davis Highway, Suite 1204, Arlington, VA 22202-4302, and to the Office of Management and Budget, Paperwork Reduction Project (0704-0188). Washington, DC 20503.

\begin{tabular}{|l|l|l|}
\hline 1. AGENCY USE ONLY (Leave blank) & 2. REPORT DATE & 3. REPORT TYPE AND DATES COVERED
\end{tabular}

4. TITLE AND SUBTITLE

September 2000

Technical Memorandum

Technical Report Series on the Boreal Ecosystem-Atmosphere Study (BOREAS) BOREAS Forest Cover Data Layers over the SSA-MSA in Raster Format

\section{AUTHOR(S)}

Jaime Nickeson and Fran Gruszka

Forrest G. Hall, Editor

\section{PERFORMING ORGANIZATION NAME(S) AND ADDRESS (ES)}

Goddard Space Flight Center

Greenbelt, Maryland 20771

5. FUNDING NUMBERS

923

RTOP: 923-462-33-01
9. SPONSORING / MONITORING AGENCY NAME(S) AND ADDRESS (ES)

National Aeronautics and Space Administration

Washington, DC 20546-0001
8. PEFORMING ORGANIZATION REPORT NUMBER

2000-03136-0

\section{SUPPLEMENTARY NOTES}

J. Nickeson: Raytheon ITSS, NASA Goddard Space Flight Center, Greenbelt, Maryland; F. Gruszka: Saskatchewan Environment and Resource Management (SERM), Prince Albert, SK, Canada

\begin{tabular}{l|l}
\hline 12a. DISTRIBUTION / AVAILABILITY STATEMENT & 12b. DISTRIBUTION CODE \\
Unclassified-Unlimited & \\
Subject Category: 43 & \\
Report available from the NASA Center for AeroSpace Information, \\
7121 Standard Drive, Hanover, MD 21076-1320. (301) $621-0390$.
\end{tabular}

13. ABSTRACT (Maximum 200 words)

This data set, originally provided as vector polygons with attributes, has been processed by BORIS staff to provide raster files that can be used for modeling or for comparison purposes. The original data were received as ARC/INFO coverages or as export files from SERM. The data include information on forest parameters for the BOREAS SSA-MSA. Most of the data used for this product were acquired by BORIS in 1993; the maps were produced from aerial photography taken as recently as 1988. The data are stored in binary, image format files.

\begin{tabular}{l} 
14. SUBJECT TERMS \\
BOREAS, remote sensing science, SERM. \\
\begin{tabular}{l|} 
17. SECURITY CLASSIFICATION \\
OF REPORT \\
Unclassified
\end{tabular} \\
$\begin{array}{c}\text { 18. SECURITY CLASSIFICATION } \\
\text { OF THIS PAGE } \\
\text { Unclassified }\end{array}$ \\
\hline
\end{tabular}

19. SECURITY CLASSIFICATION OF ABSTRACT

Unclassified
15. NUMBER OF PAGES

15

16. PRICE CODE
20. LIMITATION OF ABSTRACT

UL 
